Article

\title{
Assessment of Effective Dose from Radioactive Isotopes Contained in Mineral Waters Received by Patients During Hydrotherapy Treatments
}

\author{
Maria Karpińska ${ }^{1}{ }^{*}$, Jacek Kapała ${ }^{1}$, Agnieszka Raciborska ${ }^{1}$ and Stanisław Mnich ${ }^{2}$ \\ 1 Department of Biophysics, Medical University of Bialystok, Mickiewicza 2A, 15-222 Bialystok, Poland; \\ jacek.kapala@umb.edu.pl (J.K.); agnieszka.raciborska@umb.edu.pl (A.R.) \\ 2 The State Higher School of Computer Science and Business Administration in Lomza, Akademicka 14, \\ 18-400 Lomza, Poland; mnich@umb.edu.pl \\ * Correspondence: maria.karpinska@umb.edu.pl
}

Received: 19 November 2019; Accepted: 20 December 2019; Published: 27 December 2019

\begin{abstract}
Hydrotherapy is a natural treatment and health protection method. Treatments using natural mineral water are gaining popularity as an alternative to pharmacotherapy or as additional support to pharmacotherapy in many types of diseases. The aim of the study was to determine the effective dose obtained as a result of baths and inhalations using popular mineral water samples. A total of 18 commercially available water samples used in hydrotherapy were tested for their radioactive isotope content. The following isotopes were found: ${ }^{40} \mathrm{~K},{ }^{208} \mathrm{Tl},{ }^{212} \mathrm{Bi},{ }^{212} \mathrm{~Pb},{ }^{214} \mathrm{Bi},{ }^{214} \mathrm{~Pb}$, ${ }^{226} \mathrm{Ra},{ }^{228} \mathrm{Ac},{ }^{234} \mathrm{Th}$. Effective doses received by patients during inhalation and bathing using the tested mineral water samples were determined. The collected sample activity was measured using gamma spectrometry. The effective doses received by patients from a series of inhalation treatments ranged from 170.4 to $22.9 \mu \mathrm{Sv}$. Infants receive the highest effective dose as a result of inhalation of mineral water. The doses received by patients as a result of bathing in the studied mineral water samples were in the range of from 0.04 to $1.1 \mu \mathrm{Sv}$ and were comparable with doses from ordinary baths in tap water $(0.06 \mu \mathrm{Sv})$. The determined doses are very low; thus, they are unlikely to cause noticeable biological effects.
\end{abstract}

Keywords: inhalation; hydrotherapy

\section{Introduction}

In recent years, there has been growing interest in natural treatments and health protection methods. The health-promoting properties of various types of water used in health resorts and spas have been confirmed by long-term observations and clinical studies. Curative water is considered a mineral resource, and its use and protection are regulated by the Polish Geological and Mining Law (2011) [1] and the Polish Act on Pharmaceutical Law (2001) [2]. Pursuant to the Polish Geological and Mining Law, therapeutic water is currently defined as groundwater that is not chemically or microbiologically contaminated, characterized by natural variability of physical and chemical properties with a content of dissolved solid mineral components not less than $1000 \mathrm{mg} \mathrm{dm}^{-3}$ or one of the following: ferrous ion-no less than $10 \mathrm{mg} \mathrm{dm}^{-3}$; fluoride ion-no less than $2 \mathrm{mg} \mathrm{dm}^{-3}$; iodide ion-no less than $1 \mathrm{mg}$ $\mathrm{dm}^{-3}$; bivalent sulfur-no less than $1 \mathrm{mg} \mathrm{dm}^{-3}$; metasilicic acid-no less than $70 \mathrm{mg} \mathrm{dm}^{-3}$; radon-no less than $74 \mathrm{~Bq} \mathrm{dm}^{-3}$; unbound carbon dioxide-no less than $250 \mathrm{mg} \mathrm{dm}^{-3}$. Hydrotherapy uses brine, sulphide, peat mud, and other types of water in baths, inhalations, mouth rinses, and wet compresses. The suitability of mineral water is assessed on the basis of the microelement content, such as sodium, bromine, iodine, boron, manganese, calcium, as well as bicarbonate and chloride anions, not taking into account radioactive elements widely available in the natural environment. 
Naturally occurring radionuclides in water mainly come from three radioactive series $\left({ }^{235} \mathrm{U},{ }^{238} \mathrm{U}\right.$, and ${ }^{232} \mathrm{Th}$ ). These radioactive series are the source of 43 radioactive isotopes. In addition, water may contain radioactive potassium ${ }^{40} \mathrm{~K}$, whose activity concentration always remains in a constant ratio $(0.012 \%)$ to stable potassium ${ }^{39} \mathrm{~K}$. Natural radionuclides and their decay products are transported with water extracted from bore-holes and later used in therapeutic treatments. Bathing can lead to external exposure, while inhalation and mouth rinsing to internal exposure.

There are few estimations of the effective dose received by patients during balneological treatments as a result of ionizing radiation and its impact on the body, and mainly cover radiation caused by radon ${ }^{222} \mathrm{Rn}[3-6]$ or drinking mineral water [5,7-11].

It is important to determine the content of natural and artificial radioactive substances present in water samples used for inhalation and bathing because these treatments have recently been more widely used in outpatient treatment. Inhalations are particularly popular for treating upper respiratory tract infections in children. Introduction of mineral water with increased radioisotope content through inhalation may burden the patients with an additional dose that should be estimated.

The aim of the study was to collect information on the content of natural radioactive isotopes in commercially available therapeutic water samples used in hydrotherapy, and to determine the inhalation and skin dose from the isotopes contained therein received by patients.

\section{Materials and Methods}

Samples for testing are commercially available. We purchased all the types of mineral water intended for bathing and inhalation available on the Polish market. The sample descriptions are presented in Table 1. Measurement of sample activity was performed by gamma spectrometry, using a CANBERRA spectrometric set with a 34.8\% coaxial germanium detector and Genie2000 computer system for spectral collection and analysis. This method ensures lower detection limits, using Marinelli geometry $(450 \mathrm{~mL})$, calculated using the method according to Lloyd A. Currie, at a level of $0.1 \mathrm{~Bq} \mathrm{~L}^{-1}$.

The detector is placed in a lead shielding with a wall thickness of $10 \mathrm{~cm}$, lined with two layers of aluminum and copper sheeting. The same measurement time of 160,000 s was used for all samples.

Table 1. Description of samples.

\begin{tabular}{ccc}
\hline No. & Sample Name & Description of Sample \\
\hline 1 & Zabłocka iodine-bromine brine mist & Source Dębowiec near Skoczów \\
2 & Rabczańska iodine-bromine brine & "Krakus" spring at Rabka Zdrój \\
3 & Zabłocka iodine-bromine thermal salt & Source Debowiec near Skoczów \\
4 & Rabczańska Thermal Brine & Source “Rabka" IG-2 at Rabka Zdrój \\
5 & Kołobrzeg peat mud water & Kolobrzeg Health Resort \\
6 & Dziedzilla water & Source "Dziedzilla" at Szczawa \\
7 & Solec Zdrój sulfur water & Solec Zdrój Health Resort \\
8 & Ciechocinek brine water 1 & Ciechocinek mineral spring \\
9 & Ciechocinek brine water 2 & Ciechocinek mineral spring \\
10 & Szczawa water & Source "Szczawa I" at Szczawa \\
11 & Konstanciń therapeutic brine water & Source "Warszawa IG" at Konstancin Zdrój Health Resort \\
12 & Kołobrzeska iodine-mineral brine & Source no. 7 “Warcisław" at Kołobrzeg Health Resort \\
13 & Goczałkowice Zdrój brine for inhalation & Goczałkowice- Zdrój Health Resort \\
14 & Goczałkowice Zdrój bath brine & Goczałkowice- Zdrój Health Resort \\
15 & Połczyńska brine & Source "IG-1" at Połczyn Health Resort \\
16 & Ciechocińska bath brine & Ciechocinek Health Resort \\
17 & Bath brine from Zabłocie & Bore-hole "Korona" at Zabłocie Solanka Health Resort \\
18 & Brine from Zabłocie for inhaling & Bore-hole "Korona" at Zabłocie Solanka Health Resort \\
19 & municipal water & supply in Białystok \\
\hline
\end{tabular}

\section{Results and Discussion}

A total of 18 commercially available water samples used for baths, compresses and inhalations were collected. According to classification: 
$-3 \mathrm{~g} \mathrm{~L}^{-1}-$ poorly mineralized

3-10 $\mathrm{g} \mathrm{L}^{-1}$-average mineralization

$>10 \mathrm{~g} \mathrm{~L}^{-1}$-highly mineralized [12]

It was found that highly mineralized water predominated in the studied group (14). The radioactive isotope content in 18 mineral water samples used for inhalation and bathing was determined. The following isotopes were found: ${ }^{40} \mathrm{~K},{ }^{208} \mathrm{Tl},{ }^{212} \mathrm{Bi},{ }^{212} \mathrm{~Pb},{ }^{214} \mathrm{Bi},{ }^{214} \mathrm{~Pb},{ }^{226} \mathrm{Ra},{ }^{228} \mathrm{Ac},{ }^{234} \mathrm{Th}$.

The total (of all) isotopes radioactivity content in water and its mineralization are presented in Table 2. The reference level was the total activity and mineralization of water supplied by the municipal water supply system in Białystok (sample number 19).

Table 2. Total activity and mineralization of mineral water samples.

\begin{tabular}{ccc}
\hline No. & $\begin{array}{c}\text { Total Activity } \\
\text { (Bq L }^{-1} \text { ) }\end{array}$ & $\begin{array}{c}\text { Mineralization } \\
\text { (g) }\end{array}$ \\
\hline 1 & 8 & 1.44 \\
2 & 9 & 24.17 \\
3 & 6 & 183.44 \\
4 & 8 & 21.0 \\
5 & 5 & 60.0 \\
6 & 7 & 5.70 \\
7 & 8 & 17.07 \\
8 & 26 & 5.87 \\
9 & 52 & 5.87 \\
10 & 11 & 17.13 \\
11 & 11 & 71.17 \\
12 & 13 & 56.73 \\
13 & 140 & 74.5 \\
14 & 43 & 71.3 \\
15 & 11 & 101.52 \\
16 & 14 & 47.38 \\
17 & 12 & 42.52 \\
18 & 9 & 42.64 \\
19 & 9 & 0.9 \\
\hline
\end{tabular}

The largest total activity was demonstrated by the "Goczałkowice Zdrój brine for inhalation" sample $\left(140 \mathrm{~Bq} \mathrm{~L}^{-1}\right)$; it was highly mineralized. In the tested water samples, four isotopes had the highest specific activity: ${ }^{40} \mathrm{~K},{ }^{226} \mathrm{Ra},{ }^{228} \mathrm{Ac},{ }^{234} \mathrm{Th}$. The radioactivity of the isotope content in the tested water samples is shown in Figure 1. 


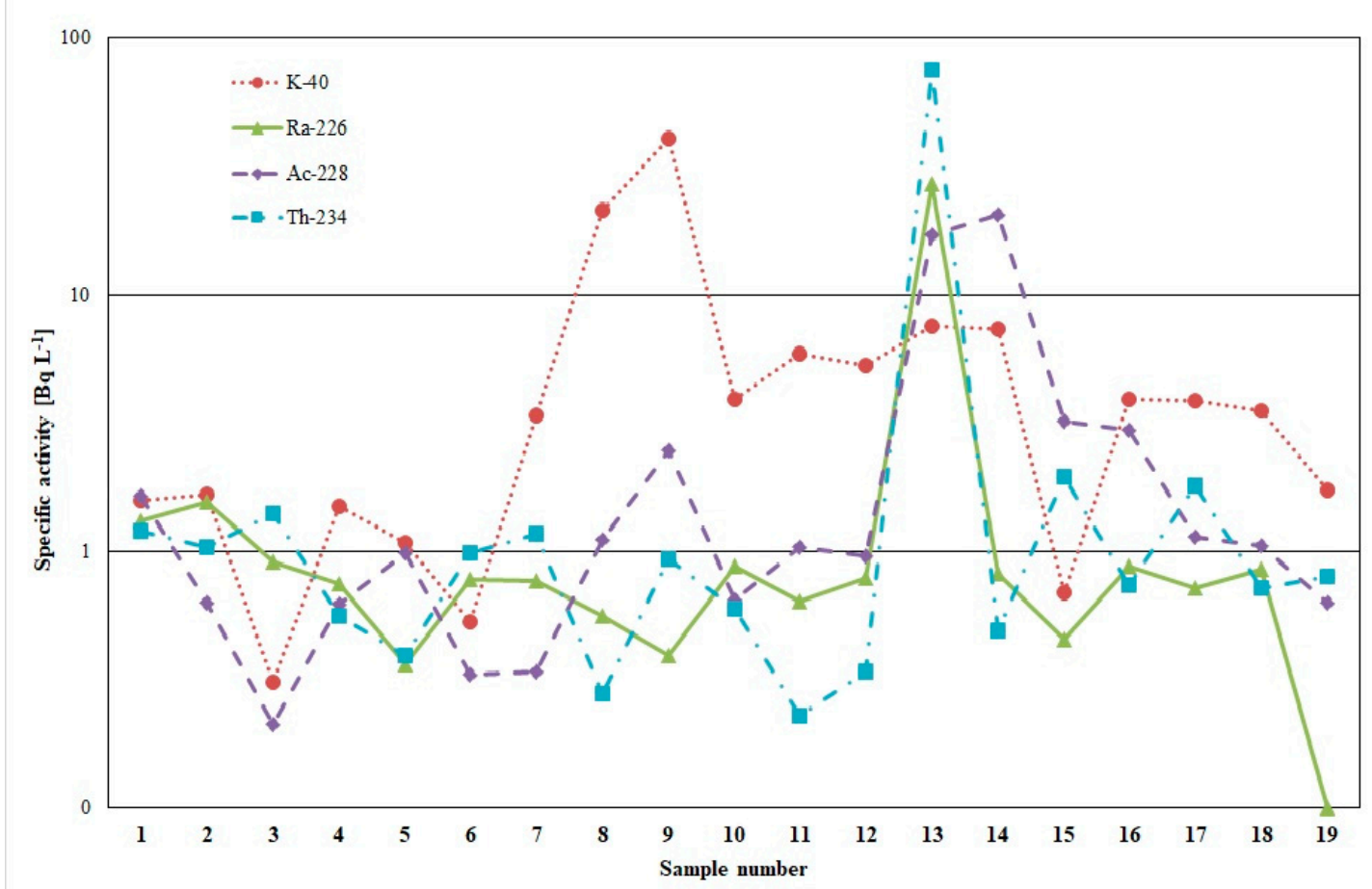

Figure 1. Specific activity of the main isotopes in the tested water samples used in balneology. For comparison, sample number 19 is water from the Białystok water supply system.

\subsection{Inhalations}

The incidence of respiratory diseases has increased in recent decades. Air pollution plays a significant role in the pathogenesis of chronic respiratory diseases [13]. Inhalation is the unquestioned method of treating respiratory diseases [14]. These treatments are used particularly often in children with upper respiratory tract infections [15].

Inhalation doses received by infants, preschool-aged children, and adults as a result of treatments with mineral water intended for inhalation were determined. The manufacturer informed about the possibility of using a given water for this type of treatment. In total, 20 treatments were assumed, $200 \mathrm{~mL}$ of water was used for each treatment. The effective dose was determined using the following equation:

$$
\mathrm{E}_{\mathrm{i}}=\mathrm{e}(\mathrm{g}) \times \mathrm{A}
$$

where: A—absorbed activity, e(g)—effective loading dose from inhalation $1 \mathrm{~Bq}$.

The estimated effective dose values from radioisotopes absorbed by inhalation for adults, children, and infants are presented in Table 3.

The effective dose received by adults as a result of using the aforementioned mineral water samples for inhalation was also estimated. The obtained results are presented in Table 4.

The effective doses received by patients from a series of inhalation treatments ranged from 170.4 to $22.9 \mu \mathrm{Sv}$. Radium, which was present in the mineral water samples from $76 \%$ to $98.8 \%$, had the greatest contribution to the effective dose obtained as a result of inhalation of children, as well as adults. In each age group, the highest value of the effective dose received via inhalation was received by patients using Goczałkowice Zdrój brine for inhalation. 
Table 3. Effective doses (in $\mu \mathrm{Sv}$ ) from all the radioisotopes contained in water samples- $\mathrm{E}_{\mathrm{i}}$ and ${ }^{226} \mathrm{Ra}$ contribution to this dose received by infants, children aged 1-2 and 2-7 years as a result of inhalation of mineral water.

\begin{tabular}{ccccccc}
\hline \multirow{2}{*}{ Sample Number } & \multicolumn{2}{c}{$\leq \mathbf{1}$ year } & \multicolumn{2}{c}{$\mathbf{1 - 2}$ years } & \multicolumn{2}{c}{$\mathbf{2 - 7}$ years } \\
\cline { 2 - 7 } & ${ }^{\mathbf{2 2 6}} \mathbf{R a}$ & $\mathbf{E}_{\mathbf{i}}$ & ${ }^{\mathbf{2 2 6}} \mathbf{R a}$ & $\mathbf{E}_{\mathbf{i}}$ & ${ }^{\mathbf{2 2 6}} \mathbf{R a}$ & $\mathbf{E}_{\mathbf{i}}$ \\
\hline 1 & 8.24 & 8.50 & 2.98 & 3.17 & 1.74 & 1.81 \\
2 & 9.73 & 10.10 & 3.52 & 3.74 & 2.06 & 2.13 \\
4 & 4.68 & 5.00 & 1.69 & 1.91 & 0.99 & 1.05 \\
5 & 2.25 & 2.50 & 0.81 & 0.97 & 0.48 & 0.52 \\
6 & 4.87 & 5.10 & 1.76 & 1.93 & 1.03 & 1.08 \\
12 & 4.93 & 5.70 & 1.78 & 2.32 & 1.04 & 1.25 \\
13 & 168.42 & 170.40 & 60.89 & 62.22 & 35.63 & 36.07 \\
14 & 5.12 & 6.70 & 1.85 & 2.95 & 1.08 & 1.44 \\
15 & 2.81 & 3.30 & 1.02 & 1.31 & 0.59 & 0.68 \\
16 & 5.43 & 6.10 & 1.96 & 2.40 & 1.15 & 1.31 \\
18 & 5.30 & 5.70 & 1.92 & 2.21 & 1.12 & 1.25 \\
\hline
\end{tabular}

Table 4. Effective doses from Ra-226 and all isotopes (in $\mu \mathrm{Sv}$ ) received by adults as a result of inhalation of mineral water samples.

\begin{tabular}{ccc}
\hline \multirow{2}{*}{ Sample Number } & \multicolumn{2}{c}{$>\mathbf{1 7}$ years } \\
\cline { 2 - 3 } & ${ }^{\mathbf{2 2 6}} \mathbf{R a}$ & $\mathbf{E}_{\mathbf{i}}$ \\
\hline 1 & 1.11 & 1.14 \\
2 & 1.31 & 1.35 \\
4 & 0.63 & 0.67 \\
5 & 0.30 & 0.33 \\
6 & 0.66 & 0.69 \\
12 & 0.66 & 0.76 \\
13 & 22.67 & 22.94 \\
14 & 0.69 & 0.89 \\
15 & 0.38 & 0.45 \\
16 & 0.73 & 0.81 \\
18 & 0.71 & 0.76 \\
\hline
\end{tabular}

\subsection{Baths}

Baths and compresses made of balneological raw materials are a fairly common treatment method, especially for adults. Thermal mineral water bathing is a recognized treatment for many diseases. Studies conducted in Turkey and Italy confirmed statistically significant greater improvement in the clinical status of patients treated with thermal mineral baths compared with the control group who used only pharmacotherapy. Some studies indicated a long-term maintained analgesic effect of thermal baths $[16,17]$.

The effective dose from beta and gamma radiation received by adults as a result of mineral water bathing (manufacturer's recommendations) was determined. A cycle of 20 treatments of 30 min each was assumed. We assumed that $90 \%$ of the skin is immersed and that the water is not diluted.

The effective dose $E_{\beta}$ from the beta emitters was determined from the dependence

$$
\mathrm{E}_{\beta}=\mathrm{A} \times \mathrm{w} \times \mathrm{s} \times \mathrm{T} \times \beta
$$

where: $\mathrm{A}$-surface activity in $\mathrm{Bq} \mathrm{cm} \mathrm{cm}^{-2}$, T-exposure time in hours, $\beta$-conversion ratio of Sv $\mathrm{h}^{-1}$ to $\mathrm{Bq}$ $\mathrm{cm}^{-2}$ [18], w-skin weighting factor 0.01 , s-fraction of immersed skin.

The dose from gamma radiation obtained from compact isotopes in the bath was determined using the following equation:

$$
\mathrm{E}_{\gamma}=\mathrm{A} \times \mathrm{DCF}_{\mathrm{ef}} \times \mathrm{t}
$$


where:

$\mathrm{DCF}_{\mathrm{ef}}$ - conversion factor of $\mathrm{Sv} \mathrm{s}^{-1}$ to $\mathrm{Bq} \mathrm{m}^{-2}$,

$\mathrm{T}$-time in $\mathrm{s}$,

A-surface activity $\mathrm{Bq} \mathrm{m}^{-2}$.

Doses were not determined from alpha emitters received through the skin because alpha particles do not reach the depth at which sensitive basal cells are found in the epidermis 50-100 $\mu \mathrm{m}$ [19]. For practical calculation purposes, the ICRP recommends using a value of $70 \mu \mathrm{m}$ [19-21]. In the measured water samples, the present isotopes that emit $\alpha$ molecules have too little energy to reach the basal cells.

Table 5 shows the determined doses from gamma and beta radiation obtained as a result of bathing. The last item, which serves as a reference, contains the doses received from analogous treatments with tap water.

Table 5. Doses from beta and gamma radiation received after 20 half-hour baths.

\begin{tabular}{cc}
\hline Sample Number & E $(\mu \mathrm{Sv})$ \\
\hline 2 & 0.05 \\
3 & 0.04 \\
4 & 0.05 \\
5 & 0.04 \\
7 & 0.06 \\
8 & 0.24 \\
9 & 0.49 \\
11 & 0.09 \\
12 & 0.1 \\
13 & 1.1 \\
14 & 0.37 \\
15 & 0.091 \\
16 & 0.12 \\
17 & 0.1 \\
19 & 0.06 \\
\hline
\end{tabular}

Doses received by patients as a result of bathing in the tested mineral water samples (intended for this purpose) ranged from 0.04 to $1.1 \mu \mathrm{Sv}$ and were much lower than those received as a result of inhalation, and comparable with the doses received as a result of normal bathing in tap water $(0.06 \mu \mathrm{Sv})$.

Exposure to natural ionizing radiation is one of the therapies used in balneology. The performed treatments include baths, inhalations, and drinking of mineral water. One of the most popular in hydrotherapy is radon water. Patients undergo radon baths $\left({ }^{222} \mathrm{Rn}\right.$ concentration higher than $74 \mathrm{~Bq}$ $\mathrm{L}^{-1}$ ) and are treated with radon inhalations. It was found that radon inhalation treatment of patients with arthritis reduced oxidative stress, strengthened immune response, and reduced pain [22]. Patients suffering from rheumatoid arthritis and treated for four weeks with baths containing radon at a concentration of $1.3 \mathrm{kBq} \mathrm{L}^{-1}$ felt marked improvement. The authors believe that the accompanying radon inhalations had an effect on reduced pain perception [23].

In the Heviz health resort (Hungary), patients received a dose of $81 \mu \mathrm{Sv}$ from ${ }^{222} \mathrm{Rn}$ and its derivatives during a two-week treatment with water baths and accompanying inhalations. Spring water containing radon had a much lower dose, $1.4 \mu \mathrm{Sv}$ [24].

In the 34 tested mineral water sources in the Kłodzko Valley, there were clear differences in the radionuclide content, which resulted in patients receiving significantly different doses during 14 days of treatment. Depending on the source, patients received doses from 0.92 to $28.9 \mu \mathrm{Sv}$. The lowest value was recorded at the Pieniawa Józefa II water source in Polanica Zdrój, and the highest at the Jerzy water source in Lądek Zdrój [7]. Exposure to elevated ${ }^{222}$ Rn concentrations in the Tapolca cave (Hungary) of 
patients suffering from lung diseases caused the absorption of doses from 0.18 to $4.22 \mathrm{mSv}$, depending on therapy duration [4].

The effective dose received by patients during peat mud treatment in Polish health resorts from beta and gamma emitters contained in the mud bath was low, i.e., $0.022 \mu \mathrm{Sv}$ [24].

Comparing the dose received during mineral water treatments with the dose received from radon at home by the inhabitants of northeastern Poland $(1.8 \mathrm{mSv})$, we found that the effective dose obtained during bathing or inhalation therapy is at least an order of magnitude smaller [25]. Measurements of isotope activity and dose calculations, both for bathing and inhalation, complete the gap in knowledge about patient exposure during hydrotherapy procedures.

For decades, the matter of assessing the biological effects of low-dose radiation has been the subject of research and controversy. Although the linear dose-effect relationship is still officially accepted, there are papers describing the beneficial health effects of low doses of ionizing radiation, i.e., radiation hormesis [26-30].

In studies investigating radiation hormesis, the radiation doses used ranged from a few to $200 \mathrm{mSv}$ [27-30]. The proposed mechanisms explaining this phenomenon are supposed to be based on stimulating the apoptosis of cells that have slipped from immune surveillance, reducing oxidative stress, and strengthening immune reactions. The papers published thus far in the literature are quite far from comprehensive understanding of this phenomenon [29].

Without commenting on the truth of the radiation hormesis hypothesis, it should be noted that in the majority of studies on this phenomenon doses from 40 to 200 mGy were used, whereby visible effects of the exposures used were observed. The estimated doses received during treatment with mineral water were much smaller.

\section{Conclusions}

There are few papers determining the effective doses in baths with mineral water. The literature on determining inhalation doses from isotopes contained in mineral water concerns mainly radon. In the study, effective doses obtained from radioactive isotopes present in mineral water samples used in balneological treatments were determined. They ranged from 0.3 to $170.4 \mu \mathrm{Sv}$ for inhalations and from 0.04 to $1.1 \mu \mathrm{Sv}$ for baths. The determined values are very small doses. The authors studying radiation hormesis obtained relatively small radiobiological effects at doses about two orders of magnitude higher. Generally, the inhalation dose is usually the highest among the doses received during balneological treatments. This is particularly true about the most commonly used radon inhalations. In the case of thermal inhalations, the dose for the lungs can reach over $5 \mathrm{mSv}$ during 14 days of treatment [6]. In light of modern radiobiological knowledge, it is difficult to assume that such small doses that we determined could cause noticeable clinical effects.

Author Contributions: Conceptualization: M.K., J.K. and S.M.; Data curation: M.K. and J.K.; Formal analysis: A.R.; Funding acquisition: J.K.; Investigation: M.K. and J.K.; Methodology: J.K.; Project administration: M.K.; Resources: A.R.; Visualization: J.K.; Writing—original draft: M.K.; Writing—review \& editing: M.K., J.K., A.R. and S.M. All authors have read and agreed to the published version of the manuscript.

Funding: This work was supported by the research project SUB/1/DN/19/003/1136 of the Medical University of Bialystok.

Conflicts of Interest: The authors declare no conflict of interest. The funders had no role in the design of the study; in the collection, analyses, or interpretation of data; in the writing of the manuscript, or in the decision to publish the results.

\section{References and Notes}

1. Polish Geological and Mining Law. Act of 9 June 2011, (consolidated text: Journal of Laws. 2011 item 163).

2. The Pharmaceutical Law Act of September 6, 2001 (consolidated text: Journal of Laws of 2019, item 499).

3. Ibrahim, S.A.; Li, S.K. Chemical enhancer solubility in human stratum corneum lipids and enhancer mechanism of action on stratum corneum lipid domain. Int. J. Pharm. 2010, 383, 89-98. [CrossRef] [PubMed] 
4. Kavasi, N.; Somlai, J.G.; Kovacs, T.; Schabo, T.; Varhegyi, A.; Hakl, J. Occupational and patient doses in the therapeutic cave, Tapolca (Hungary). Radiat. Prot. Dosim. 2003, 106, 263-266. [CrossRef] [PubMed]

5. Somlai, J.; Torma, A.; Dobrovari, P.; Kavasi, N.; Nagy, K.; Kovacs, T. Contribution of Rn-222, Ra-226, U-234 and U-238 radionuclides to the occupational and patient exposure in Heviz-spas in Hungary. J. Radioanal. Nucl. Chem. 2007, 272, 101-106. [CrossRef]

6. Tempfer, H.; Hofmann, W.; Schober, A.; Lettner, H.; Dinu, A.L. Deposition of radon progeny on skin surfaces an resulting radiation doses in radon therapy. Radiat. Environ. Biophys. 2010, 49, 249-259. [CrossRef] [PubMed]

7. Walencik-Łata, A.; Kozłowska, B.; Dorda, J.; Przylibski, T.A. The detailed analysis of natural radionuclides dissolved in spa waters of the Kłodzko Valley, Sudety Mountains, Poland. Sci. Total Environ. 2016, 569, 1174-1189. [CrossRef] [PubMed]

8. Csondor, K.; Bajak, P.; Surbeck, H.; Izsak, B.; Horvath, A. Transient natura of riverbank filtered drinking water supply systems-A new challenge of natural radioactivity assessment. J. Environ. Radioact. 2020, 211, 106072. [CrossRef] [PubMed]

9. Dicu, T.; Burghele, B.D.; Cucos, A.; Mishra, R.; Sapra, B.K. Assessment of annual effective dose from exposure to natural radioactivity sources in a case-control study in Bihor County, Romania. Radiat. Prot. Dosim. 2019, 185, 15-24. [CrossRef]

10. Silva, C.R.E.; Machado, D.V.; da Silva-Filho, E.V. Determination of the natural radioactivity in the mineral water distributed in the Salutaris Park, Paraíba do Sul, Brazil. Environ. Earth Sci. 2019, 78, 639. [CrossRef]

11. Bonotto, D.M. Gross alpha/beta radioactivity and radiation dose in thermal and non-thermal spas groundwaters. Heliyon 2019, 5, e01563. [CrossRef]

12. Marchacz, W. Hydrogeology; Wydawnictwa Geologiczne: Warszawa, Poland, 1960; pp. 240-244.

13. Bukowczan, Z.; Kurzawa, R.; Bukowczan, J. Epidemiologia chorób alergicznych oraz analiza czynników środowiskowych. Acta Pneumonol. Allergol. Pediatr. 2004, 7, 55-61. (In Polish)

14. Grabicki, M.; Batura-Gabryel, H. Use of aerosol therapy in pulmonary diseases. Przew Lek. 2008, 2, 89-95. (In Polish)

15. Alkiewicz, J. Aerozoloterapia w chorobach układu oddechowego u dzieci. Przew Lek. 2009, 4, $106-111$.

16. Fraioli, A.; Grassi, M.; Mennuni, G.; Geraci, A.; Petraccia, A.; Fontana, M.; Conte, S.; Serio, A. Clinical researches on the efficacy of spa therapy in fibromyalgia. A systematic review. Ann. Ist. Super. Sanita 2013, 49, 219-229. [PubMed]

17. Tomczak, H.; Hansdorfer-Korzon, R.; Majkowicz, M.; Basiński, K.; Zdun-Ryżewska, A.; Tomczak, W.; Teodorczyk, J. Balneotherapy in the complex treatment of fibromyalgia: A review of selected literature. Ból 2016, 17, 33-37. [CrossRef]

18. Kocher, D.C.; Eckerman, K.F. Electron dose-rate conversion factors for external exposure of the skin from uniformly deposited activity on the body surface. Health Phys. 1987, 53, 135-141. [CrossRef]

19. International Commission on Radiological Protection. Conversion Coefficient for Radiological Protection Quantities for External Radiation Exposure, Annex G. In Special Considerations for Assessing the Local Skin-Equivalent Dose; Annals of the ICRP. Publication 116; International Commission on Radiological Protection: Ottawa, ON, Canada, 2010; Volume 40, pp. 247-250.

20. International Commission on Radiological Protection. Recommendation of the International Commission on Radiological Protection; Annals ICRP 21(1-3); International Commission on Radiological Protection: Ottawa, ON, Canada, 1991.

21. International Commission on Radiological Protection. The 2007 Recommendation of the International Commission on Radiological Protection; Annals ICRP. Publication 103; International Commission on Radiological Protection: Ottawa, ON, Canada, 2007; Volume 37.

22. Yamaoka, K.; Mitsunobo, F.; Hanamoto, K.; Mori, S.; Tanizaki, Y.; Sugita, K. Study on biologic effects of radon and thermal therapy on osteoarthritis. J. Pain 2004, 5, 20-25. [CrossRef]

23. Franke, A.; Reiner, L.; Pratzel, H.G.; Franke, T.; Resch, L.K. Long-term efficacy of radon spa therapy in rheumatoid arthritis-A randomized sham-controlled study and follow-up. Rheumatology 2000, 39, 894-902. [CrossRef]

24. Karpińska, M.; Mnich, K.; Kapała, J.; Bielawska, A.; Kulesza, G.; Mnich, S. Radioactivity of peat mud used in therapy. J. Environ. Radioact. 2016, 152, 97-100. [CrossRef] 
25. Karpińska, M.; Mnich, Z.; Kapała, J.; Szpak, A. The evaluation of indoor radon exposure in houses. Pol. J. Environ. Stud. 2009, 18, 1005-1012.

26. Dobrzyński, L.; Janiak, M.K.; Strupczewski, A.; Waligorski, M. On the need to replace the present paradigm of radiation protection-Comments by SARI (Scientists for accurate radiation information). Postepy Techniki Jądrowej 2017, 60, 2-11.

27. Lehrer, S.; Rosenzweig, K.E. Lung cancer hormesis in high impact states where nuclear testing occurred. Clin. Lung Cancer 2015, 16, 152-155. [CrossRef] [PubMed]

28. Rithidech, K.N.; Scott, B.R. Evidence for radiation hormesis after in vitro exposure of human lymphocytes to low doses of ionizing radiation. Dose Response 2008, 6, 252-271. [CrossRef] [PubMed]

29. Shi, J.; Huber, M.; Wang, T.; Dali, W.; Lin, Z.; Chun-Sheng, Y. Progress in the studies on hormesis of low-dose pollutants. Environ. Dis. 2016, 1, 58-64.

30. Yang, G.; Kong, Q.; Wang, G.; Jin, H.; Zhou, L.; Yu, D.; Niu, C.; Han, W.; Li, W.; Cui, J. Low-dose ionizing radiation induced direct activation of natural killer cells and provides a novel approach for adoptive cellular immunotherapy. Cancer Biother. Radiopharm. 2014, 29, 428-434. [CrossRef]

(C) 2019 by the authors. Licensee MDPI, Basel, Switzerland. This article is an open access article distributed under the terms and conditions of the Creative Commons Attribution (CC BY) license (http://creativecommons.org/licenses/by/4.0/). 